
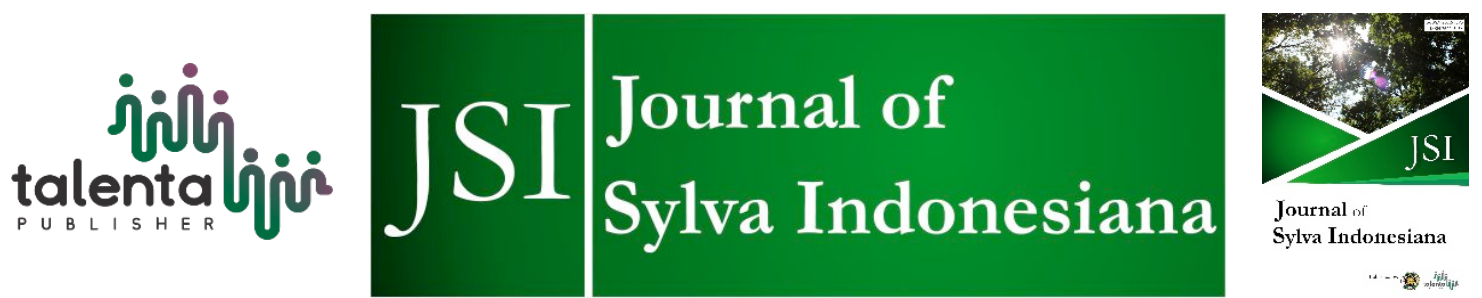

\title{
The Effect of The Addition of Promoting Microbes (PROMI) in Making Media of Pleurotus ostreatus
}

\author{
Karmila $^{1}$, Ira Taskirawati ${ }^{1 *}$, and Baharuddin ${ }^{1}$ \\ ${ }^{I}$ Faculty of Forestry, Hasanuddin University, Jl. Perintis Kemerdekaan Km. 10, Makassar, Indonesia
}

\begin{abstract}
In making oyster mushroom growing media, one of the stages that must pass is composting of growing media (baglog). It takes a week or more to compile the media at this stage, so the media is ready to be inoculated by the fungus. This long composting time, economically slow down production in the cultivation of oyster mushrooms. Thus, using an activator to speed up the composting process is often done. During this time, the most widely used activators to shorten composting time is Effective Microorganism (EM4). In this study, another type of activator with the same function as EM4 was tried, namely Promoting Microbes (PROMI). The purpose of this study to determine the effect (dose) compromise on the making of oyster mushroom growing media to mycelium growth time, pinhead growth time; harvest time; the number of the fruiting body, and the weight of fresh mushrooms. The raw material used candlenut wood sawdust (Aleurites moluccana Willd) in the making of media. The method used in this study is the making of growing media, composting, sterilization, inoculation of the fungus, and maintenance. Growing media consisted of sawn wood sawdust, PROMI, bran, $\mathrm{CaSO} 4, \mathrm{CaCO}$, and water. The treatment used is the addition of compromise to the growing media before composting. The doses of PROMI given are as follows: $0 \mathrm{~g}(\mathrm{P} 1) ; 0.25 \mathrm{~g}$ (P2); $0.5 \mathrm{~g}$ (P3), and $0.75 \mathrm{~g}$ (P4), each of which dissolved in $200 \mathrm{ml}$ of water. This study's results indicate that different PROMI when mixing raw materials influences mycelium closure in growing media and the time of harvesting mushroom fruit bodies. For the time of mycelial closing, giving as much as 0.5 $\mathrm{g}$, PROMI has different control effects. The provision of PROMI as much as $0.5 \mathrm{~g}$ and $0.75 \mathrm{~g}$ also influences the control in harvest time.
\end{abstract}

Keyword: Aleurites moluccana Willd, Mushroom Cultivation, Pleurotus ostreatus, Promoting Microbes

Received 21 November 2019| Revised 13 July 2020 | Accepted 15 July 2020

\section{Introduction}

Pleurotus ostreatus, known as the oyster mushroom, is a fungus that is easy to grow in areas with tropical and subtropical climates. The oyster mushroom is an edible mushroom species with no nutritional value and high economic and increasing market demand. Demand oyster mushrooms in Indonesia in 2014 were 1,796 tons per year [1], in 2015 the production of

\footnotetext{
*Corresponding author: Faculty of Forestry, Hasanuddin University. Jl. Perintis Kemerdekaan Km. 10, Makassar, Indonesia

E-mail address: tasqira@unhas.ac.id
} 
mushrooms 2,208 tons per year, in 2016 increased by 2,619 tons, in 2017 reached 3,031 tons per year, and in 2018 rose 3,442 tonnes per year.

Good prospects for oyster mushrooms and increasing public interest in consuming mushrooms have led to an increase in some community groups' interest in cultivating oyster mushrooms. In the oyster mushroom cultivation will utilize various media in the form of the substrate where the media has the same characteristics as the natural habitat of oyster mushrooms. The media commonly used for mushroom cultivation was sawdust, which is waste from sawmills. Wood is known to contain cellulose, hemicellulose, and lignin required for fungal growth. One type of sawdust waste that can utilize is candlenut wood waste (Aleurites moluccana Willd). Candlenut wood is a type of wood that comes from community forests. Currently, candlenut wood is used to make furniture, lighters, and pulp.

One stage in the cultivation of oyster mushroom makes a mushroom growing media or called baglog. In making planting media, one of the steps taken after mixing raw materials is the composting stage. This stage usually takes a week or more depending on the type of wood sawdust used. The composting process, which takes a long time, is undoubtedly not economically profitable. It is what causes some mushroom businesses or farmers to end up using activators aimed at accelerating the composting process. Activators commonly used type is Effective Microorganism (EM4). Some studies related to the addition of EM4 on oyster mushroom media has done. According to [2] investigated the effect of EM4 addition and composting time on mycelium and mushroom fruit bodies' growth rate. Meanwhile, according to [3] added EM4 to the production of oyster mushroom growing media using teak sawdust.

In this study, to accelerate the composting process of candlenut wood sawdust, it also gave the activator the addition. However, activators are used instead of EM4. The activator used is Promoting Microbes (PROMI). PROMI has a function similar to EM4, which can apply to degrade organic matter into compost. The active ingredients of superior microbial compromise are native to Indonesia. They have been selected and tested in research centers Biotechnology and Bioindustry Indonesia Bogor, namely Aspergillus sp., Trichoderma harzianum DT 38, and DT 39 T pseudokoningii and microbial rot. Composting with a shorter time is expected to impact the mycelium's short closing time, the time of the emergence of a pinhead, and mushroom harvest. So the purpose of this study was to determine the effect of giving (dose) PROMI on making oyster mushroom growing media on the time of mycelium growth, pinhead growth time, harvest time, the amount of fruit growing and the weight of fresh mushrooms. Hopefully, PROMI can become an alternative activator to accelerate the composting process in the manufacturing stage of mushroom growing media. 


\section{Research Method}

\subsection{Oyster Mushroom Growth Media Preparation}

The initial preparation to make mushroom growing media is to soak candlenut wood powder to remove the extractive substances one day. After soaking, the sawdust is dried in the sun until it reaches air dry and is ready to be used as a planting medium. Baglog making media consist of candlenut wood sawdust (Aleurites moluccana Willd), bran, casts (CaSO4), lime (CaCO3), and water and PROMI mixed evenly. There were four treatments applied for PROMI doses in this study, namely P1 as control without PROMI, P2 (0.25 g PROMI activator), P3 (0.5 g PROMI activator), and P4 (0.75 g activator PROMI). The growing media mixture was composted for two days. PROMI serves to shorten the composting process; naturally, the composting process requires a week or more. The composting process, with or without PROMI, causes microorganisms that live on the growing media. If these microorganisms are left alive, it will interfere with the inoculation of oyster mushrooms. The next stage in this activity is sterilizing the growing media in an autoclave sterilizer with $121^{\circ} \mathrm{C}$ temperature for two hours. Later, the media is ready to be inoculated with fungi in the incubation room and continued with fungal maintenance.

\subsection{Variables Observed}

The variables observed in this study were:

a. Mycelium growth time. The time of mycelium growth was calculated from the growth media inoculated by fungi until all parts of the growing media were covered by mycelium (days).

b. Time prospective growth of fungal fruiting bodies (pinhead). Pinhead growth time is calculated from growth media inoculated by fungi until the appearance of a pinhead from the mouth of the ring (day). Pinhead-sized likes a pin $\pm 1 \mathrm{~cm}$.

c. Harvest time. The harvest time is calculated from the inoculated growing media until the oyster mushrooms harvested.

d. Mushroom wet weight. Weight of fresh mushrooms after a harvest, calculated in grams.

e. The number of mushroom fruit bodies. The number of fungal fruiting bodies produced at the time of harvesting.

\subsection{Data analysis}

The experiments arrange in a Completely Randomized Design (CRD), which was repeated three times. The data were analyzed using analysis of variance to determine the effect of treatment. To determine the different effects between treatments continued with Tukey's Honestly Significant Difference Test at the 5\% test level [4]. 


\section{Results and Discussion}

Naturally, oyster mushrooms grow on logs that have rotted or are in the process of decomposition. Oyster mushroom itself is one of the agents that accelerates the decomposition process. In the cultivation of oyster mushrooms, growing media, commonly referred to as baglog, is made to resemble a log of wood that has undergone decay. Thus, the composting process is one of the stages that passed in the process of making media. Promoting Microbes (PROMI) is an activator that is used to help shorten the composting time. Naturally, the process of composting media takes one week or more, depending on the type of wood sawdust used. So, the use of PROMI on this media will shorten the composting time from usually less than one week to only two days. This media is expected to be used the same as naturally composted media, both in mycelium closure time, pinhead growth, and harvesting time.

\subsection{Growth of Oyster Mushroom Mycelium}

The mycelium formation is early in the development phase before the formation of pinhead mushrooms (primordia), or the candidate will be fruiting. The mycelium will form small nodules which later evolved into the pinhead and eventually formed limbs and mushroom fruit bodies [5]. The oyster mushroom mycelium's length after the inoculation of the growing media is presented in Figure 1.

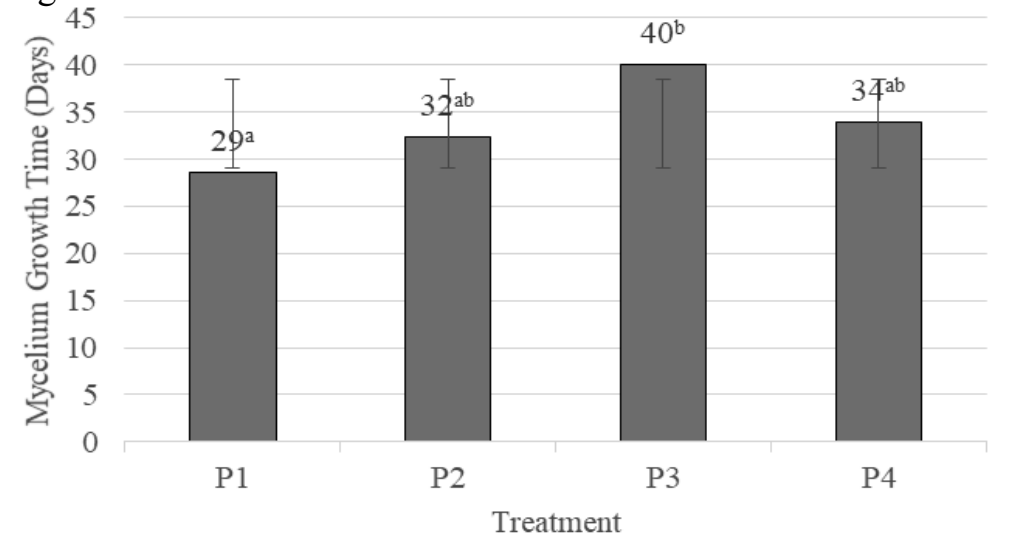

Figure 1 Duration of oyster mushroom mycelium growth in the media after growing media inoculation of oyster mushroom seeds (days) [P1: control, P2: $0.25 \mathrm{~g}, \mathrm{P} 3: 0.5 \mathrm{~g}$ and P4: $0.75 \mathrm{~g}$ ]. Different notation letters behind the numbers indicate a significant difference $(\mathrm{P}<0.05)$

Treatment P1 (without PROMI activator) is growth media with the fastest closing of oyster mushroom mycelium, with a growth period of 29 days. Meanwhile, treatment P3 (0.5 g PROMI activator) is growth media with mycelium closure no longer than 40 days. Figure 1 shows the addition of PROMI to the production of oyster mushroom growing media has a significant difference $(\mathrm{p}<0.05)$ to the time of mycelium growth. Tukey's Honestly Significant Difference Test showed that treatment P1 (without PROMI activator) differed from treatment P3 (0.5 g PROMI activator). However, the treatment P2 (0.25 g PROMI activator) and P4 (0.75 g PROMI activator) did not differ from the treatment $\mathrm{P} 1$ and $\mathrm{P} 3$. 
The duration of mycelium spread is one indicator of the success of inoculation. If the growth media is not overgrown with mycelium, then mushroom seeds' inoculation on the growing media is declared a failure. In this study, the length of mycelium covering the growing medium ranged from 29 to 40 days. According to [6], the media's entire surface grew white evenly by mycelium after 20-30 days from inoculation. According to [7], the long observations of mycelium were carried out up to 25 days because, at 25 days, there was already one of ten treatments whose planting media had fulfilled by mycelium. Another study conducted by [8] stated that mycelium covered the growing media between 18-38 days. The range of mycelium closure in this study can be said to be not so different from previous studies. What is unique in this study is that the growth media that do not get the addition of PROMI (P1) become the fastest-growing media covered by mycelium, compared to other growth media that reach the addition of PROMI. Candlenut wood is a type of low-natural durability wood. Candlenut wood is straightforward to be attacked by colorant mushrooms, both in the form of boards and in sawdust formation. This characteristic that allows mycelium is direct to cover the mushroom growing media.

The growth of oyster mushroom mycelium will be achieved in an incubation chamber, which has a temperature in 22 to $29^{\circ} \mathrm{C}$. During the day, temperatures above $29^{\circ} \mathrm{C}$ fungi can still grow with somewhat inhibited growth and stunted yields [9]-[10]. The ideal humidity for the incubation chamber is $90-100 \%$ [10]. This study's temperature range is $22-29^{\circ} \mathrm{C}$, while moisture at room temperature incubation in this study ranges from 48-96\%. According to [10] added that another factor which causes the mycelium will be challenging to grow and spread across the surface of the growing medium is when the growing medium is too dense.

\subsection{Growth of Oyster Mushroom Pinhead}

After the vegetative phase or the growth of spores and mycelium, mushroom fruit bodies are the next step. The nucleus of plasma and spores that form loose or joined cells that form hyphae and mycelium, at the juncture of branching mycelium will create small spots called pinhead (candidate for fungal bodies) that will develop into fruit mushroom bodies [11]-[12]. Pinhead is a fruit body candidate whose fruiting body's appearance is calculated from inoculation until the pinhead-sized like $\mathrm{a} \pm 1 \mathrm{~cm}$ pinheads out of the ring mouth [11]. The average length of pinhead growth in oyster mushroom cultivation after the media was grown in the inoculation of oyster mushroom seeds presented in Figure 2.

Treatment P3 (0.5 g PROMI activator) is the fastest growing medium of pinhead growth that is 49 days since the media grew in fungal inoculation. Meanwhile, treatment P1 (without PROMI activator) and P4 (0.75 g PROMI activator) are growing media with the longest pinhead growth time of 53 days. The results of the analysis of variance showed that the addition of PROMI to the production of oyster mushroom growing media did not have a significant difference in the time of pinhead growth. 


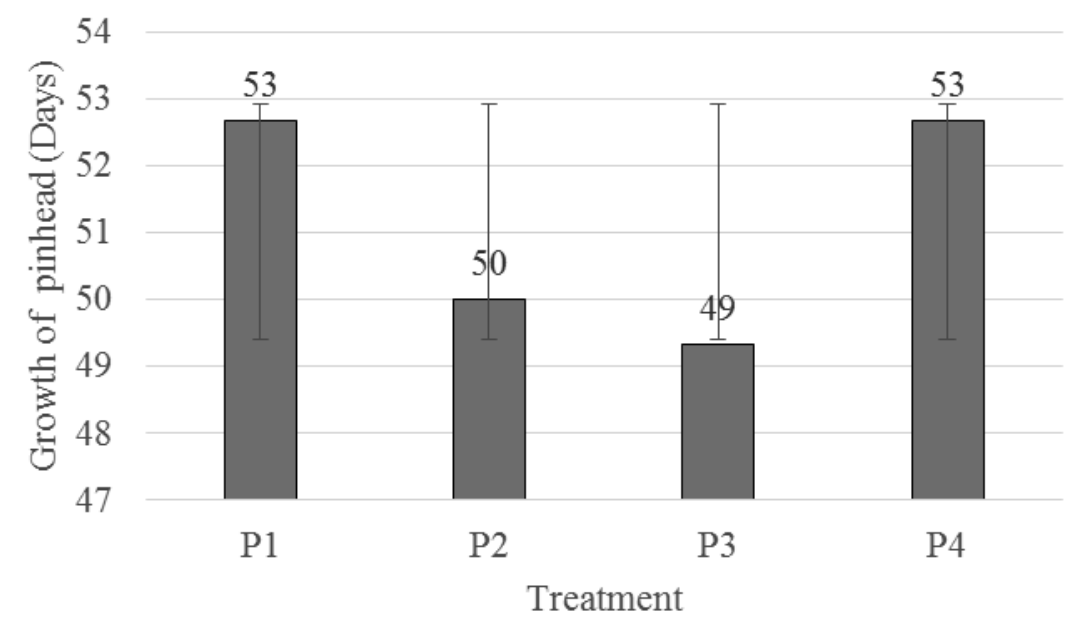

Figure 2 Pinhead growth time [P1: control, P2: $0.25 \mathrm{~g}, \mathrm{P} 3: 0.5 \mathrm{~g}$ and P4: $0.75 \mathrm{~g}]$

Suppose calculated from the time of complete mycelium closure on growing media. It takes approximately seven days after the transplanting media is removed in the growth chamber; the prospective fruiting body (pinhead) will grow [7]. After planting media transfer in the growth chamber, it took nine days to pinhead growth (P3 growing media with $0.5 \mathrm{~g}$ PROMI activator). According to [3] stated that pinhead growth is directly proportional to the length of mycelium growth in growing media. It is not in line with this study's results where the length of growth of pinhead fungus is not directly proportional to the length of fungal mycelium cover. Treatment P3 (0.5 g PROMI activator) where the mycelium growth was the slowest, but the pinhead growth time was the fastest. In contrast, in the treatment P1 (without PROMI activator) where mycelium closure duration is the quickest but the most extended pinhead growth.

\subsection{Oyster Mushroom Harvesting}

During the hood's edge are still folds then said to be immature fruiting bodies; if the edge of the hood in full bloom, the fruit body reaches its adult stage and can be harvested [12].

\section{A. $\quad$ Oyster Mushroom Harvesting Time}

The harvest time also calculated, starting from the fungus inoculation on the growing media. The average length of time to harvest is presented in Figure 3. It takes the fastest time of 52 days (P3: $0.5 \mathrm{~g}$ PROMI activator) to harvest oyster mushrooms from growing media inoculated by mushrooms. 


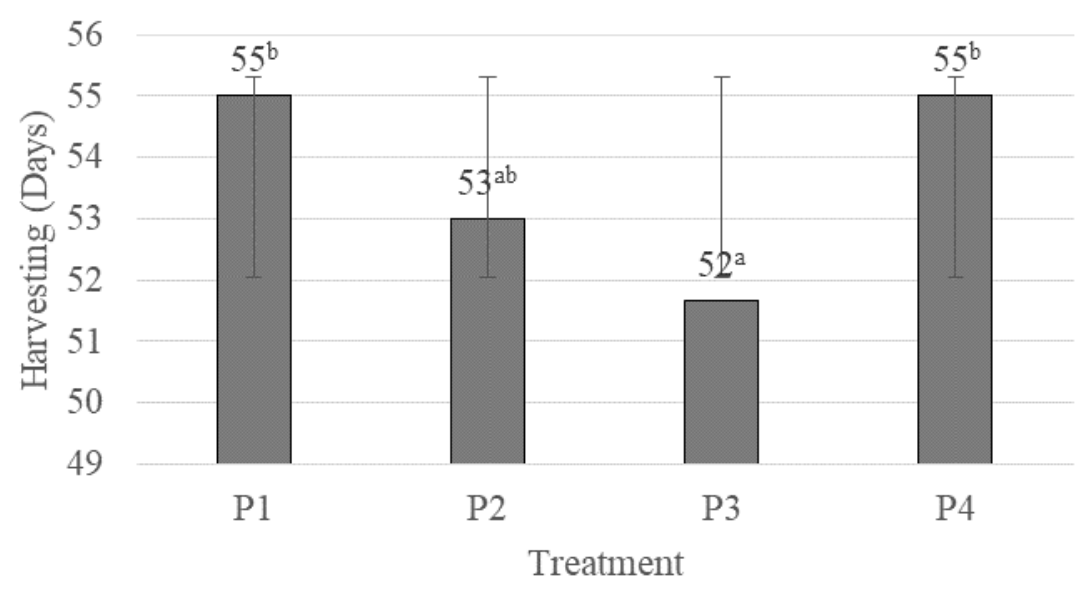

Figure 3 Harvest Time [P1: control, P2: $0.25 \mathrm{~g}, \mathrm{P} 3: 0.5 \mathrm{~g}$ and P4: $0.75 \mathrm{~g}$ ]. Different notation letters behind the numbers indicate a significant difference $(\mathrm{P}<0.05)$

Figure 3 shows the addition of PROMI to the production of oyster mushroom growing media has a significant difference $(\mathrm{p}<0.05)$ to harvest time. The results of Tukey's Honestly Significant Difference Test showed that P3 (0.5 g PROMI activator) growth media were different from P1 (without PROMI activator) growth media and P4 (0.75 g PROMI activator). However, the growth media P2 (PROMI activator $0.25 \mathrm{~g}$ ) is no different from other growth media.

For example, in this study, for the treatment P3 (0.5 g PROMI activator), the time for pinhead appearance was 49 days since the media inoculated. The time for harvesting was 52 days since the media inoculated. It means that it takes three days from the appearance of pinhead until mushrooms are ready for harvesting. According to [7], the mushroom fruit body has developed optimally approximately 2-4 days after the prospective fruit body grows. In this condition, the mushroom fruit body will have thinner edges and be ready to be harvested. This statement is in line with this study, were in this study, the mushroom fruit body was prepared to be harvested after 2-3 days from the appearance of the oyster mushroom fruit body.

\section{B. Wet weight Oyster Mushroom Fruit Body}

The shorter time to create a baglog due to the shortened composting process, with the PROMI activator's help, is expected to impact the mushroom harvest. At the very least, the mushrooms are harvested, producing the same with mushrooms produced from baglog with composting time is longer. Harvesting of oyster mushrooms cannot separate from how many mushrooms produced at each baglog and how many pieces of the body produced at each baglog-figure 4 shown the average fresh weight of mushrooms fruit bodies in oyster mushroom cultivation. 


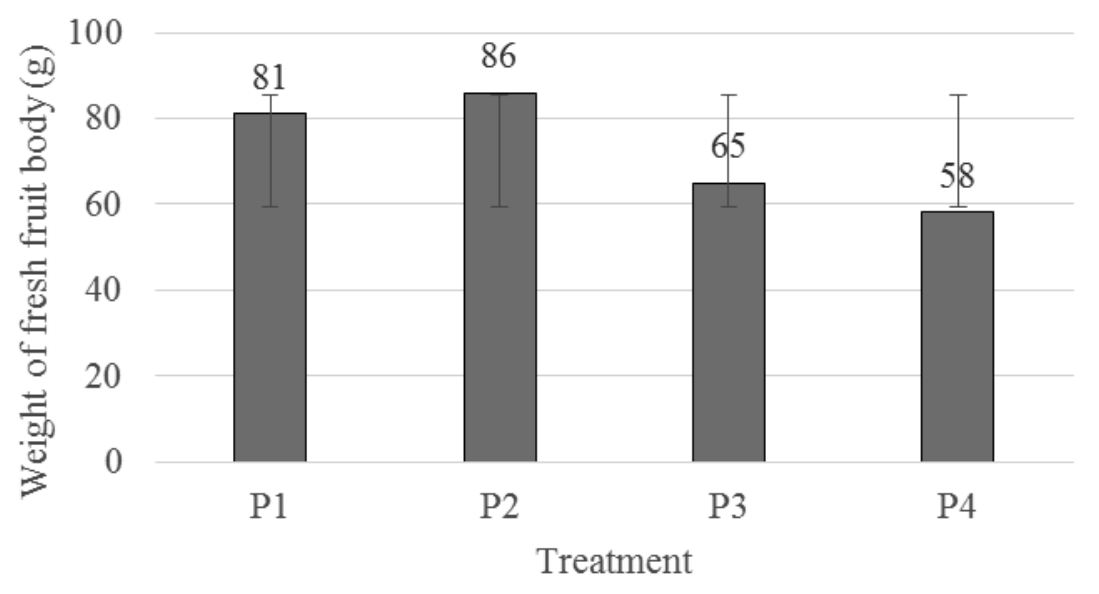

Figure 4 The wet weight of oyster mushroom fruit body [P1: control, P2: $0.25 \mathrm{~g}, \mathrm{P} 3,0.5$ $\mathrm{g}$ and P4: $0.75 \mathrm{~g}$ ]

The variance analysis showed that the addition of PROMI in the making of oyster mushroom growing media did not significantly differ in the wet weight of the oyster mushroom fruit bodies. According to [13], which uses waste decomposers dry leaves, and the addition of EM4 result that the addition of EM4 does not affect the wet weight of the fruiting bodies of oyster mushrooms harvested. Although the activators used in this study are different (in this study using PROMI), the results obtained are in line with the addition of PROMI activators, which also does not affect the wet weight and number of mushroom fruit bodies.

Fresh mushrooms produced in this study, are not much different from previous studies. In this study, the treatment P2 (0.25 g PROMI activator) was the growing medium that produced the most mushrooms, as many as $86 \mathrm{~g}$. Meanwhile, treatment P4 (0.75 g PROMI activator) is a growing medium that produces the least amount of mushrooms, as many as $58 \mathrm{~g}$. According to [3], using the teak wood sawdust as media and the using EM4 activator when making the media produce fresh mushrooms on average, $90 \mathrm{~g}$ per media grows. Meanwhile, according to [8], can harvest fresh mushrooms an average of $67 \mathrm{~g}$ per media grown using sago pulp and rice husk as media.

\section{Number of Oyster Mushroom Fruit Body}

The formation of the fruit body cells is much inseparable from the existence of compounds needed by the fungus on the growing medium in considerable amounts. Nutrients required for mycelium growth and fruit body development of oyster mushrooms are significant components of the cell wall. The element of the cell wall is cellulose, hemicellulose and lignin and protein. After decomposing, this compound will produce nutrients needed by the fungus [14]. In this study, the nutrients required for mycelium growth and body development of oyster mushrooms were found in the growing media, namely candlenut sawdust. Candlenut wood contains the main components, namely cellulose ranging from $4.44 \%$, hemicellulose, and lignin $24.9 \%$. 
Besides wood sawdust, bran is also a source of additional nutrients - the average number of mushroom fruit bodies in oyster mushroom cultivation is presented in Figure 5.

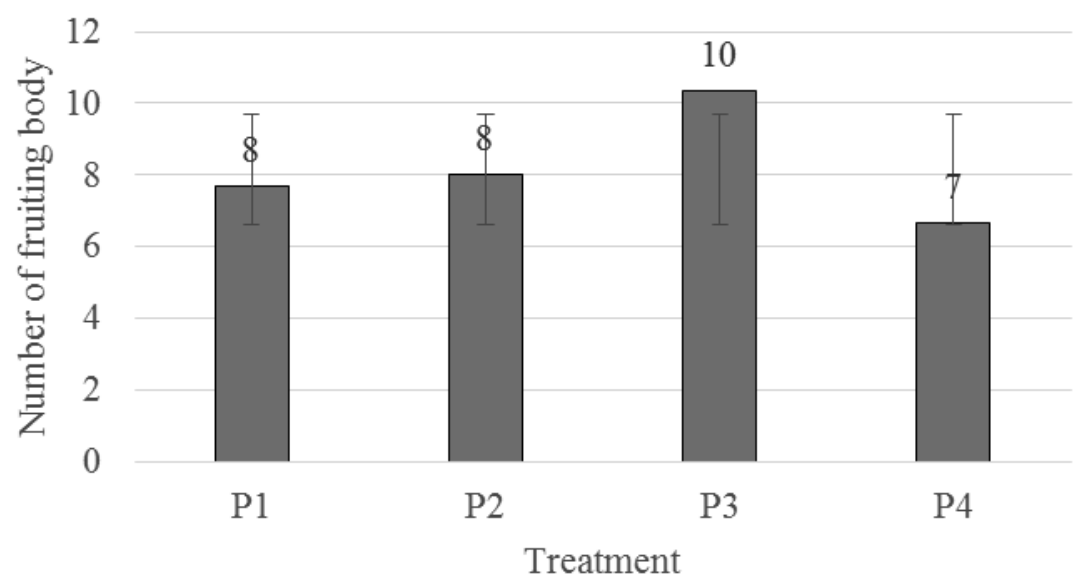

Figure 5 Number of oyster mushroom fruit bodies [P1: control, P2: $0.25 \mathrm{~g}, \mathrm{P} 3: 0.5 \mathrm{~g}$ and P4: $0.75 \mathrm{~g}]$

Figure 5 shows the number of fruit bodies produced between 7-10 pieces per growing medium. According to [15], the optimal growth of fruit body numbers can reach 8-10 fruit bodies per growing media. Just like the wet weight, the results of the analysis of variance showed that the addition of PROMI in the making of oyster mushroom growing media did not have a significant difference in the number of oyster mushroom fruit bodies. This study is in line with research conducted by [16] and [17] were in both of these studies, explained that the type of growing media did not influence the number of fruiting bodies produced.

\section{Conclusion}

The addition of promoting-microbes activator in the making result of oyster mushroom growing media influences the mycelium closure time on the planting media and harvest time. Treatment P3 (0.5 g PROMI activator) differs from treatment P1 (without PROMI activators) in the growth of mycelium time and harvest time. The use of growing media ( $0.5 \mathrm{~g}$ PROMI activator) takes 52 days from media inoculation until the mushrooms are ready to be harvested.

\section{REFERENCES}

[1] R. Abdisobar, A. Bakar, and Yuniar, "Analisis Kelayakan Usaha Budidaya Jamur Tiram Di Desa Cilame Ciwidey Kabupaten Bandung," J. Online Inst. Teknol. Nas., vol. 02, no. 01, pp. 168-179. 2014.

[2] W. R. Andayanie, "Penambahan EM4 dan Lama Pengomposan Media Tanam Terhadap Pertumbuhan dan Hasil Jamur Tiram Putuh (Pleurotus florida)," Agritek, vol. 14, no. 1, pp. 33-41. 2013.

[3] M. Ilyas, I. Taskirawati, and A. Arif, "Pemanfaatan Limbah Serbuk Kayu Jati (Tectona grandis) sebagai Media Tumbuh Jamur Tiram (Pleurotus ostreotus)," Perennial, vol. 14, no. 2, pp. 47-50. 2018.

[4] V. Gaspersz, Metode Perancangan Percobaan, Bandung, CV ARMICO, 1991. 
[5] A. R. Ginting, N. Herlina, and S. Y. Tyasmoro, "Studi Pertumbuhan Dan Produksi Jamur Tiram Putih (Pleorotus ostreatus) Pada Media Tumbuh Gergaji Kayu Sengon Dan Bagas Tebu," J. Produksi Tanam., vol. 1, no. 2, pp. 17-24. 2013.

[6] Susilawati and B. Raharjo, "Budidaya Jamur Tiram (Pleourotus ostreatus var florida) yang Ramah Lingkungan,” Palembang, Report No. 50.STE.Final, 2010.

[7] A. Rochman, "Perbedaan Proporsi Dedak Dalam Media Tanam Terhadap Pertumbuhan Jamur Tiram Putih (Pleurotus florida)," J. Agribisnis Fak. Pertan. Unita, vol. 11, no. 13, pp. 56-67. 2015.

[8] I. Taskirawati, Rosdiana, and Baharuddin, "Sago pulp and rice husk as an alternative material for the cultivation of oyster mushroom (Pleurotus ostreatus )," in ICFSSAT 2020, pp. 1-7. 2020.

[9] H. U. Suriawiria, Budi Daya Jamur Tiram, Yogyakarta, Kanisius, 2002.

[10] S. Stevani, Pengaruh Penambahan Molase Dalam Berbagai Media Pada Jamur Tiram (Pleurotus osteratus), Universitas Sebelas Maret Surakarta, 2011.

[11] I. N. T. Yanuati, Kajian perbedaan Komposisi Media Tanam Terhadap Pertumbuhan dan Hasil jamur Tiram Putih (Pleurotus florida), Universitas Brawijaya, Malang, 2007.

[12] P. Ayu, Budidaya Jamur Tiram, 1st ed. Bandung, Putra Danayu Publisher, 2016.

[13] D. W. Afriadi, A. M. Hudha, and S. Zaenab, "Pengaruh Pemanfaatan Limbah Dedaunan sebagai Pengganti Serbuk Kayu dengan Bantuan Pengurai Em4 Terhadap Hasil Produksi Jamur Tiram Putih (Pleurotus ostreatus) sebagai Sumber Belajar Biologi," in Prosiding Seminar Nasional Pendidikan Biologi, 2015, no. 2007, pp. 339-345.

[14] Baharuddin, M. T. Arafah, and Syahidah, "Pemanfaatan Serbuk Kayu Jati (Tectona grandis L.) yang Direndam dalam Air Dingin Sebagai Media Tumbuh Jamur Tiram (Pleurotus comunicipae)," Perennial, vol. 2, no. 1, pp. 1-5. 2006.

[15] M. Nurjayadi, Bisnis Jamur Tiram di Rumah Sendiri, Bogor, Institut Pertanian Bogor Press, 2009.

[16] F. T. Sitompul, E. Zuhry, and Armaini, "Effects Of Various Growth Media And Addition Of Sucrose To The Growth Of White Oyster Mushroom (Pleurotus ostreatus)," JOM Faperta, vol. 4, no. 2, pp. 1-15. 2017.

[17] T. Suryani and H. Carolina, "Pertumbuhan Dan Hasil Jamur Tiram Putih Pada Beberapa Bahan Media Pembibitan," Bioeksperimen J. Penelit. Biol., vol. 3, no. 1, p. 73.2017. 